\title{
Entdecken Sie den Unterschied!
}

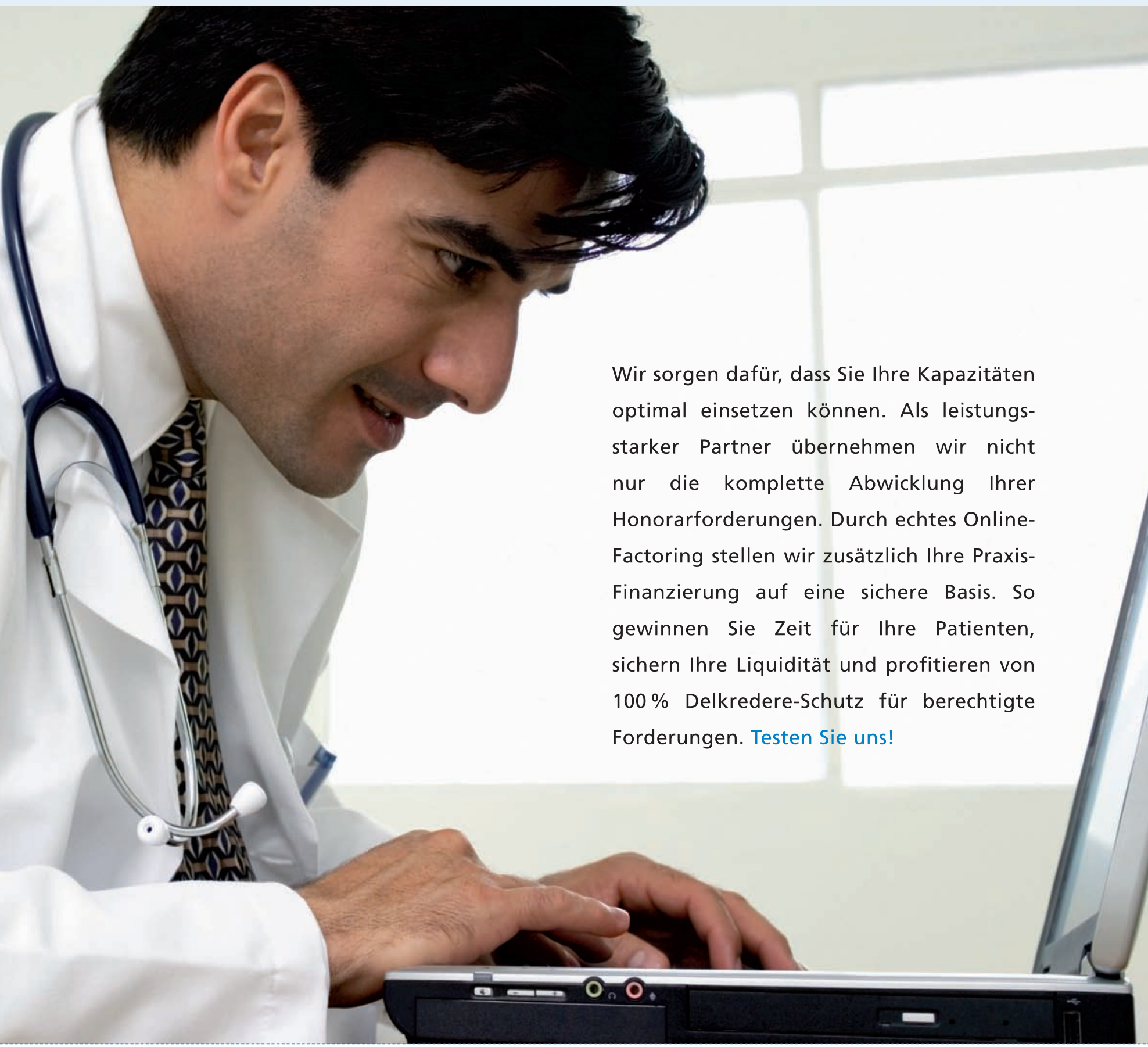

\section{Online-Honorarabrechnung mit FMH Factoring Services}

$\checkmark$ Bitte senden Sie mir unverbindlich und kostenlos Unterlagen über das komplette Leistungspaket.

$\square \quad$ Ich wünsche eine persönliche Beratung. Bitte rufen Sie an:

Telefon: Beste Anrufzeit:

Ansprechpartner:

Adresse/Stempel:
Antworttalon: Bitte einsenden oder per Fax an 0325603911 